\title{
Study of the surface evolution of nitrogen species on $\mathrm{CuO} / \mathrm{CeZrO}_{2}$ catalysts
}

\author{
Monika Radlik • Małgorzata Adamowska • \\ Agata Lamacz • Andrzej Krztoń • Patrick Da Costa • \\ Wincenty Turek
}

Received: 3 October 2012/Accepted: 24 February 2013/Published online: 13 March 2013

(C) The Author(s) 2013. This article is published with open access at Springerlink.com

\begin{abstract}
A series of $\mathrm{CuO} / \mathrm{CZ}$ catalysts with different amounts of copper oxide were synthesized from copper nitrates by incipient wetness impregnation of the ceria-zirconia support. The structural, redox, acidic and adsorption properties were investigated using X-ray diffraction (XRD), BET, $\mathrm{H}_{2}$ temperature programmed reduction $\left(\mathrm{H}_{2}\right.$-TPR), temperature programmed desorption of $\mathrm{NO}$ in the presence of oxygen (NO-TPD) and in situ diffuse reflectance infrared Fourier transform spectroscopy (DRIFTS). The results have shown good catalytic activity for $\mathrm{CuO} /$ $\mathrm{Ce}_{0,62} \mathrm{Zr}_{0,38} \mathrm{O}_{2}$ in $\mathrm{NO}$ oxidation to $\mathrm{NO}_{2}$. Species such as nitrites and nitrates were formed on the surface. The transformation of nitrite compounds into nitrate was observed above $200{ }^{\circ} \mathrm{C}$. From 300 up to $400{ }^{\circ} \mathrm{C}$, decomposition of the surface nitrate to nitrite was discerned. Ammonia was adsorbed on the Lewis and Brønsted acid sites on $\mathrm{Cu} / \mathrm{CZ}$ catalyst surface during temperature programmed reactions. The evolution of adsorbed $\mathrm{NH}_{3}$ species to $\mathrm{NH}_{2}$ surface group was confirmed by formation specific band of absorption at $1528 \mathrm{~cm}^{-1}$.
\end{abstract}

Keywords TPD $\cdot$ TPR $\cdot$ DRIFTs $\cdot \mathrm{Cu} / \mathrm{CZ} \cdot \mathrm{deNO}_{\mathrm{x}} \cdot \mathrm{Ammonia}$

M. Radlik · W. Turek $(\bowtie)$

Institute of Physical Chemistry and Technology of Polymers, Silesian University of Technology, M.Strzody 9, 44-100 Gliwice, Poland

e-mail: Wincenty.Turek@polsl.pl

\section{Adamowska · P. D. Costa}

Institut Jean Le Rond d'Alembert, CNRS UMR 7190, Université Pierre et Marie Curie, Paris 6, 2 place de la gare de ceinture, 78210 Saint-Cyr-l'École, France

\section{A. Łamacz · A. Krztoń}

Polish Academy of Sciences, Centre of Polymer and Carbon Materials, M. Curie-Skłodowskiej 34, 41-819 Zabrze, Poland 


\section{Introduction}

The exhaust gases from stationary and mobile combustion sources containing, among others, nitrogen oxides, i.e. $\mathrm{NO}$ and $\mathrm{NO}_{2}$, are a major source of air pollution. These nitrogen oxides lead to photochemical smog, acid rain and ozone depletion $[1,2]$. In order to decrease the $\mathrm{NO}_{\mathrm{x}}$ emissions according to the environmental emission standards, a various catalytic methods have been developed, e.g. the threeway catalysts for gasoline fuelled vehicles, $\mathrm{NO}_{\mathrm{x}}$ storage-reduction systems for lean burn engines or the selective catalytic reduction (SCR) processes for the large-scale combustion facilities [3-5]. The selective catalytic reduction of $\mathrm{NO}_{\mathrm{x}}$ has been widely studied. The key roles in this process are played by both the catalyst and the reducing agent, which can be ammonia, urea or hydrocarbons. Ammonia is considered to be the most active in the selective catalytic reduction of $\mathrm{NO}_{\mathrm{x}}(\mathrm{SCR}-$ $\mathrm{NH}_{3}$ ) [10].

Various catalysts such as zeolites, metal oxides and noble metal catalysts have been widely investigated in the deNO $\mathrm{N}_{\mathrm{x}}$ process $[1,4,5]$. These catalysts should be active in the interaction with $\mathrm{NO}$ and have properties to oxidize $\mathrm{NO}$ to $\mathrm{NO}_{2}$, which is more favored to $\mathrm{NO}_{\mathrm{x}}$ conversion under oxidizing conditions, such as the technique of the selective catalytic reduction of $\mathrm{NO}_{\mathrm{x}}$, especially with some $\mathrm{N}$-containing as agents like ammonia or urea $\left(\mathrm{NH}_{3}-\mathrm{SCR}\right)$ [6]. Unfortunately, all these catalysts exhibit a lot of disadvantages. For example commonly used commercial catalysts, e.g. $\mathrm{V}_{2} \mathrm{O}_{5}-\mathrm{WO}_{3} / \mathrm{MnO}_{3}$ or $\mathrm{V}_{2} \mathrm{O}_{5}-\mathrm{WO}_{3} / \mathrm{TiO}_{2}$, at high temperatures oxidize $\mathrm{SO}_{2}$ to $\mathrm{SO}_{3}$, which can give sulfuric acid and, as a consequence, result in corrosion and deposition of solid by-products downstream from the reactor, where the temperature is lower. Another disadvantage of $\mathrm{V}_{2} \mathrm{O}_{5}$ is its toxicity. The metal oxides, such as unsupported $\mathrm{MnO}_{\mathrm{x}}$ or $\mathrm{MnO}_{\mathrm{x}} / \mathrm{Al}_{2} \mathrm{O}_{3}$ have low deNO selectivity to $\mathrm{N}_{2}$ and produce great amounts of the $\mathrm{N}_{2} \mathrm{O}$. The noble metals, on the other hand, are expensive, suffer due to deactivation by poisoning with the sulfur compounds and have weak thermal stability, which leads to active phase aggregation. Other catalysts like zeolites have low hydrothermal stability [6-11]. A very promising alternative for the above mentioned catalysts is ceria-zirconia mixed oxide (CZ), which has attracted much attention of the researchers working on the $\mathrm{NO}_{\mathrm{x}}$ reduction in the last 20 years. The main advantages of $\mathrm{CZ}$ are good stability and unique redox properties. The labile oxygen vacancies and bulk oxygen species with relatively high mobility are easily formed during the redox shift between $\mathrm{Ce}^{3+}$ and $\mathrm{Ce}^{4+}$ under oxidizing and reducing conditions, respectively. The pure $\mathrm{CeO}_{2}$ is rarely used as a catalyst or support for $\mathrm{NO}_{\mathrm{x}}$ reduction because it has poor thermal stability. The addition of $\mathrm{ZrO}_{2}$ improves not only thermal stability but also the oxygen storage capacity and redox properties of ceria, upgrading the same its catalytic activity at lower temperatures. Furthermore, the addition of noble or transition metals (or their oxides) has a promotional effect on the redox properties and oxygen storage capacity of $\mathrm{CZ}[5,12-14]$. The catalytic activity of ceriazirconia mixed oxides depends on the $\mathrm{Ce} / \mathrm{Zr}$ ratio. Among a few $\mathrm{Ce}_{\mathrm{x}} \mathrm{Zr}_{(1-\mathrm{x})} \mathrm{O}_{2}$ supports, the $\mathrm{Ce}_{0.62} \mathrm{Zr}_{0.38} \mathrm{O}_{2}$ has been found to be the most active [15], and such support has been chosen as a support for the copper catalysts used in our studies. 
The aim of our work is to prepare and characterize catalysts, which can be potentially used for $\mathrm{NO}_{\mathrm{x}}$ removal via $\mathrm{NH}_{3}$-SCR. The ceria-zirconia supported copper catalyst $\left(\mathrm{CuO} / \mathrm{Ce}_{0.62} \mathrm{Zr}_{0.38} \mathrm{O}_{2}\right)$ was synthesized with different copper loadings and characterized using the BET method and powder X-ray diffraction (XRD). The temperature programmed reduction of the catalysts with hydrogen $\left(\mathrm{H}_{2}-\right.$ TPR) was conducted in order to evaluate the variation of their redox properties. Acidic properties have been examined by the $\mathrm{NH}_{3}$ adsorption. The catalysts have also been investigated for their ability to oxidize $\mathrm{NO}$ to $\mathrm{NO}_{2}$. According to the literature, $\mathrm{NO}_{2}$ particles are preferentially reduced when the reaction is carried out in the presence of a reductant such as ammonia. For this purpose, the experiments of temperature programmed desorption of $\mathrm{NO}$ (NO-TPD) and $\mathrm{NO}$ oxidation to $\mathrm{NO}_{2}$ were conducted. Additionally, for better understanding the structure and evolutions of species adsorbed on the catalyst surface, both experiments, i.e. NO-TPD and NO oxidation, were carried out in the DRIFT cell in controlled atmosphere.

\section{Experimental}

\section{Catalysts preparation}

The ceria-zirconia supported copper catalysts were prepared by the incipient wetness impregnation of the commercial $\mathrm{Ce}_{0.62} \mathrm{Zr}_{0.38} \mathrm{O}_{2}(\mathrm{CZ})$, provided by Rhodia Electronics \& Catalysts, with aqueous solutions of copper nitrate. After impregnation, the samples were dried at $120^{\circ} \mathrm{C}$ for $12 \mathrm{~h}$ and then calcined at $550{ }^{\circ} \mathrm{C}$ for 2 . The loading of copper was 2,4 and $10 \mathrm{wt} \%$. The obtained catalysts $\mathrm{CuO} /$ $\mathrm{Ce}_{0.62} \mathrm{Zr}_{0.38} \mathrm{O}_{2}$ were denoted as $\mathrm{Cu}(\mathrm{x}) / \mathrm{CZ}$, where $\mathrm{x}$ was the loading of $\mathrm{Cu}$.

Characterization of the catalysts

The specific surface area (Ssp) of the support and studied catalysts was determined using the BET method. The Ssp was measured by nitrogen adsorption at $77.35 \mathrm{~K}$ on the ASAP 2010 apparatus. Prior to each measurement, the samples were degassed at $105{ }^{\circ} \mathrm{C}$ until the stable vacuum of $10^{-3} \mathrm{~Pa}$ was reached. The chemical compositions of the studied catalysts were obtained by ICP.

The X-ray diffraction (XRD) measurements were performed on the Siemens D5005 apparatus (Bruker-AXS) with $\mathrm{CuK}_{\alpha}$ radiation, operating at $30 \mathrm{kV}$ and $50 \mathrm{~mA}$. The data were collected in the $2 \theta$ range of $10^{\circ}-90^{\circ}$. The phase identification was made using the JCPDS cards.

The experiments of temperature-programmed reduction $\left(\mathrm{H}_{2}\right.$-TPR) were performed using $50 \mathrm{mg}$ samples of the support and studied catalysts. The samples were reduced in hydrogen $5 \%(\mathrm{v} / \mathrm{v}) \mathrm{H}_{2} / \mathrm{Ar}$ (flow $20 \mathrm{ml} \mathrm{min}^{-1}$ ) from room temperature to $900{ }^{\circ} \mathrm{C}$ with the heating rate of $7.5^{\circ} \mathrm{C} \mathrm{min}^{-1}$. The consumption of hydrogen was monitored by the thermal conductive detector.

The experiments of temperature-programmed desorption of NO (NO-TPD) were performed using a BELCAT-M apparatus. First, NO was adsorbed at room temperature in the presence of oxygen $\left(500 \mathrm{ppm} \mathrm{NO}\right.$ and $5 \%(\mathrm{v} / \mathrm{v}) \mathrm{O}_{2} / \mathrm{Ar}$ ) for 
$60 \mathrm{~min}$. The NO-TPD experiment was carried out in flowing $5 \%(\mathrm{v} / \mathrm{v}) \mathrm{O}_{2} / \mathrm{Ar}$ from RT to $500{ }^{\circ} \mathrm{C}$ with a heating rate of $4{ }^{\circ} \mathrm{C} \mathrm{min}^{-1}$. In all experiments, the total flow rate was $250 \mathrm{ml} \mathrm{min}{ }^{-1}$ and the gas hourly space velocity was $10.000 \mathrm{~h}^{-1}$. The concentration of $\mathrm{NO}$ and $\mathrm{NO}_{2}$ gas at the detector outlet was analyzed using NDIR detector.

The evolution of surface species on $\mathrm{Cu} / \mathrm{CZ}$ catalysts during their interaction with $500 \mathrm{ppm}$ of $\mathrm{NO}+5 \%$ vol. $\mathrm{O}_{2} / \mathrm{Ar}$ at programmed temperature was studied. The in situ FTIR spectra of adsorbed species were recorded in the range of 4000-500 $\mathrm{cm}^{-1}$ using a BIORAD FTS 165 spectrometer equipped with the high temperature environmental DRIFT cell. The total gas flow was $20 \mathrm{ml} \mathrm{min}^{-1}$. In the first step, the samples were pretreated in flowing Ar at $400{ }^{\circ} \mathrm{C}$ for $0.5 \mathrm{~h}$ in order to remove water and other impurities from the catalysts surface. Then, the sample was cooled in Ar to the room temperature. The background spectra were collected from $\mathrm{RT}$ to $400{ }^{\circ} \mathrm{C}$ in flowing Ar. The spectra of catalyst surface in $\mathrm{NO}+\mathrm{O}_{2} /$ Ar were also collected from RT to $400{ }^{\circ} \mathrm{C}$ after $20 \mathrm{~min}$ of isotherm in given temperature. The same procedure was performed during interaction catalyst surface with $500 \mathrm{ppm}$ $\mathrm{NH}_{3} / \mathrm{Ar}$.

The DRIFTS spectra during the temperature programmed desorption of NO (NOTPD) were recorded as follows: first, the reaction mixture $(500 \mathrm{ppm}$ of $\mathrm{NO}+5$ vol. $\%$ of $\mathrm{O}_{2} / \mathrm{Ar}$ ) was adsorbed on the catalyst surface at $20{ }^{\circ} \mathrm{C}$ for $60 \mathrm{~min}$; then, the surface was purged with Ar for $30 \mathrm{~min}$; and finally, the temperature was increased from RT up to $400{ }^{\circ} \mathrm{C}$ in flowing Ar. The spectra of catalyst surface were collected after $10 \mathrm{~min}$ of remaining at each temperature.

Before the experiments, each sample was calcined in air for $2 \mathrm{~h}$ at $500{ }^{\circ} \mathrm{C}$ with the rate of heating $10{ }^{\circ} \mathrm{C} \mathrm{min}^{-1}$ and cooled down to room temperature.

\section{Results and discussion}

Catalyst composition and specific surface area

The chemical composition and SSA of the support and obtained catalysts are presented in Table 1. It is observed that the specific surface area decreases with increasing copper content, which can be due to the sintering of ceria-zirconia, as a consequence of impregnation process and further calcination.

Table 1 Results of the textural analysis by $\mathrm{N}_{2}$ adsorption/ desorption and composition for $\mathrm{CZ}$ and catalyst

\begin{tabular}{llllllll}
\hline $\begin{array}{l}\text { Catalysts } \\
\text { reference }\end{array}$ & \multicolumn{4}{l}{ Composition (wt\%) } & $\begin{array}{l}\mathrm{S}_{\mathrm{BET}} \\
\left(\mathrm{m}^{2} \mathrm{~g}^{-1}\right)\end{array}$ & $\begin{array}{l}\text { Pore volume } \\
\left(\mathrm{cm}^{3} \mathrm{~g}^{-1}\right)\end{array}$ \\
\cline { 2 - 5 } $\mathrm{Ce}$ & $\mathrm{Zr}$ & $\mathrm{O}$ & $\mathrm{Cu}$ & & \\
\hline $\mathrm{CZ}$ & 53.3 & 21.27 & 25.43 & 0 & 138 & 0.32 \\
$\mathrm{Cu}(2) / \mathrm{CZ}$ & 51.5 & 20.56 & 25.95 & 1.99 & 113 & 0.26 \\
$\mathrm{Cu}(4) / \mathrm{CZ}$ & 49.5 & 19.76 & 26.85 & 3.89 & 109 & 0.25 \\
$\mathrm{Cu}(10) / \mathrm{CZ}$ & 45.9 & 18.39 & 25.93 & 9.78 & 101 & 0.23 \\
\hline
\end{tabular}


X-ray diffraction (XRD)

The ceria-zirconia solid solutions $\mathrm{Ce}_{\mathrm{x}} \mathrm{Zr}_{1-\mathrm{x}} \mathrm{O}_{2}$ exist in the three stable phases: monoclinic, tetragonal, cubic and two metastable phases [16]. Fig. 1 presents the XRD pattern of the studied support and catalysts. All the diffractograms show the main reflexes typical to a fluorite cubic structure. The reflections corresponding to (111), (200), (220), (311), (222), (400) and (420) planes are observed [17]. In addition, no segregation of the individual phases such as $\mathrm{CeO}_{2}$ or $\mathrm{ZrO}_{2}$ was detected, which can be due to the incorporation the $\mathrm{Zr}^{4+}$ cations into the ceria lattice. The radius of $\mathrm{Zr}$ is $0.084 \mathrm{~nm}$ and is smaller than the radius of $\mathrm{Ce}(0.097 \mathrm{~nm})$. Such incorporation leads to formation of homogenous solid solutions [16, 18]. The XRD pattern of $\mathrm{Cu}(2) / \mathrm{CZ}$ and $\mathrm{Cu}(4) / \mathrm{CZ}$ (Fig. 1b and c) do not show any typical reflections of the $\mathrm{CuO}$ phase. It can be caused by the detection limits of this technique or due to high dispersion of the metal oxide phase. When the $\mathrm{CuO}$ content was increased to $10 \mathrm{wt} \%$ (Fig. 1d), the $\mathrm{CuO}$ crystallites formed agglomerates and the reflexes corresponding to (200), (111), (013), (022) and (222) planes of $\mathrm{CuO}$ were observed [19].

Temperature programmed reduction $\left(\mathrm{H}_{2}-\mathrm{TPR}\right)$

Fig. 2 shows the $\mathrm{H}_{2}$-TPR profiles of the support and studied catalysts. The positions of the reduction peaks $\left(T_{\max }\right)$ and values of $\mathrm{H}_{2}$ consumption are presented in

Fig. 1 XRD patterns of the support $\mathrm{CZ}(a)$ and catalysts: $\mathrm{Cu}(2) / \mathrm{CZ}(b), \mathrm{Cu}(4) / \mathrm{CZ}(c)$ and $\mathrm{Cu}(10) / \mathrm{CZ}(d)$

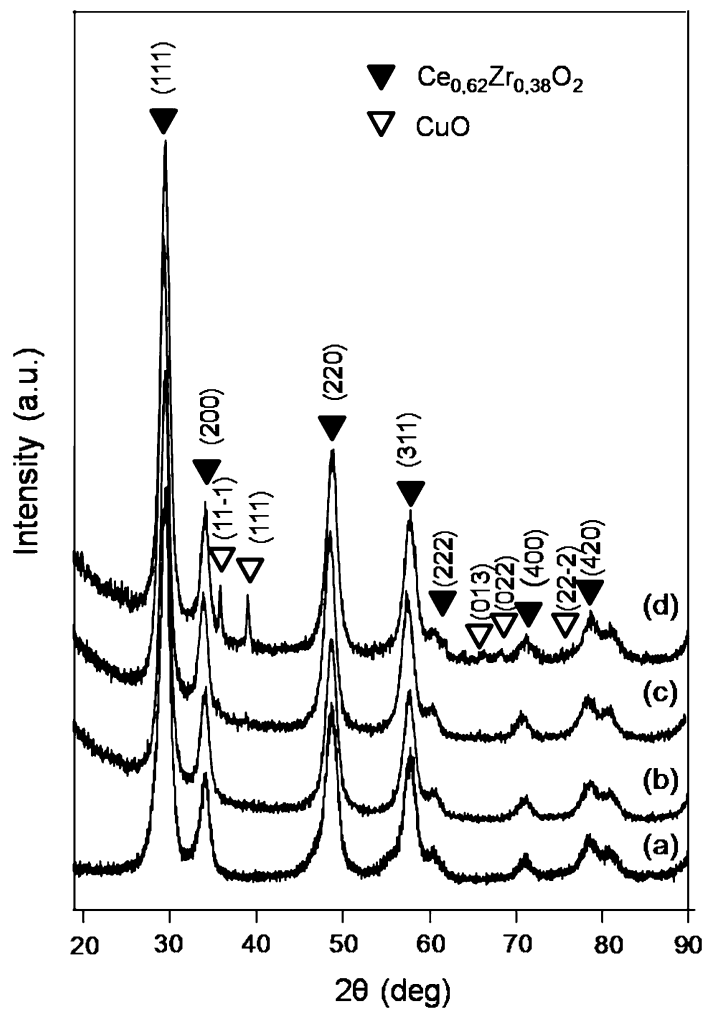


Table 2. The $\mathrm{H}_{2}$-TPR profile of pure ceria-zirconia revealed the presence of two peaks at a temperature of 377 and $557{ }^{\circ} \mathrm{C}$. These peaks suggest that the reduction of $\mathrm{CZ}$ occurs in two steps. At lower temperature, the surface ceria is reduced, whereas the reduction of bulk ceria occurs at higher temperature $[12,20]$. The reduction of ceria $\mathrm{Ce}^{4+}$ occurs according to the following equation Eq. (1) [21]:

$$
2 \mathrm{CeO}_{2}+\mathrm{H}_{2} \leftrightarrow \mathrm{Ce}_{2} \mathrm{O}_{3}+\mathrm{H}_{2} \mathrm{O}
$$

The oxygen anions are eliminated as water molecules and oxygen vacancies are formed, which promotes the mobility of oxygen from the bulk to the surface, according to Eq. 2, where $\mathrm{V}_{\mathrm{o}}$ it is oxygen vacancy [22] The $\mathrm{H}_{2}$ consumption arises only from the reduction of $\mathrm{Ce}^{4+}$ to $\mathrm{Ce}^{3+}$ because $\mathrm{Zr}^{4+}$ is the non-reducible cation [23].

$$
\mathrm{Ce}_{\mathrm{x}} \mathrm{Zr}_{1-\mathrm{x}} \mathrm{O}_{2}+\delta \mathrm{H}_{2} \leftrightarrow \mathrm{Ce}_{\mathrm{x}} \mathrm{Zr}_{1-\mathrm{x}} \mathrm{O}_{2-\delta}+\delta \mathrm{H}_{2} \mathrm{O}+\delta \mathrm{V}_{\mathrm{o}}
$$

Fig. 2 shows the $\mathrm{H}_{2}$-TPR profiles for the $\mathrm{Cu} / \mathrm{CZ}$ catalysts. Each TPR profile can be divided into two reduction areas. The first area from 100 to $180{ }^{\circ} \mathrm{C}$ can be ascribed to the reduction of surface ceria or highly dispersed $\mathrm{CuO}$. Moreover, the presence of copper oxide changes the shape of the support reduction curve and shifts the reduction into lower temperature. The second reduction area from 200 to $220{ }^{\circ} \mathrm{C}$ can be attributed to the reduction of copper oxide [21, 24], which occurs according to Eq. 3:

$$
\mathrm{CuO}+\mathrm{H}_{2} \leftrightarrow \mathrm{Cu}+\mathrm{H}_{2} \mathrm{O}
$$

Additionally, the reduction of copper oxide requires the presence of a starting point such as an oxygen vacancy on the surface, which can be formed by the reduction of surface ceria [20]. Table 2 presents temperature of the reduction peaks ( $\left.T_{\max }\right)$ and values of $\mathrm{H}_{2}$ consumption. The $\mathrm{H}_{2}$ consumption is the smallest for the

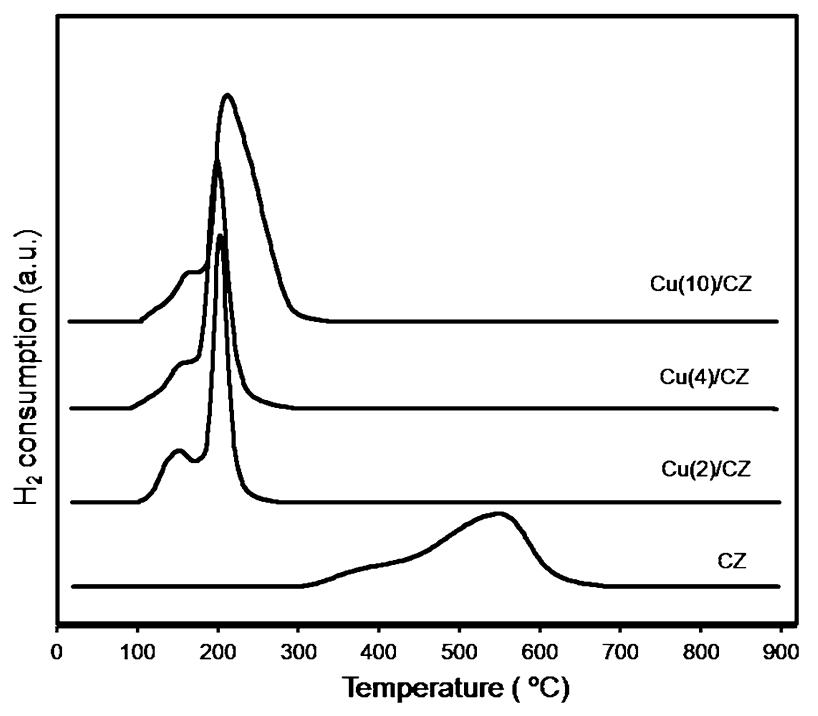

Fig. $2 \mathrm{H}_{2}$-TPR profiles of the support and $C u(2) / C Z, C u(4) / C Z, C u(10) / C Z$ catalysts 
Table $2 \mathrm{H}_{2}$ consumption during $\mathrm{H}_{2}$-TPR experiments

\begin{tabular}{lll}
\hline Catalyst & $T_{\max }\left({ }^{\circ} \mathrm{C}\right)$ & $\begin{array}{l}\mathrm{H}_{2} \text { consumption } \\
\left(\mathrm{mmol} \text { gcat }^{-1}\right)\end{array}$ \\
\hline $\mathrm{CZ}$ & 557 & 0.76 \\
$\mathrm{Cu}(2) / \mathrm{CZ}$ & 206 & 0.99 \\
$\mathrm{Cu}(4) / \mathrm{CZ}$ & 203 & 1.34 \\
$\mathrm{Cu}(10) / \mathrm{CZ}$ & 217 & 2.16 \\
\hline
\end{tabular}

support, and addition of $\mathrm{CuO}$ leads to an increase in hydrogen consumption from $\mathrm{Cu}(2) / \mathrm{CZ}$ to $\mathrm{Cu}(10) / \mathrm{CZ}$. Increasing redox properties with the increasing loading of $\mathrm{Cu}$ can be explained not only by the reducibility of $\mathrm{CuO}$ but also by the strong interaction between the copper and support. Copper is responsible for the increase of oxygen mobility. Therefore, the support is reduced at lower temperature and value of hydrogen consumption for catalysts is higher [23, 25].

Temperature programmed desorption of NO (NO-TPD) and in situ DRIFTS

The temperature programmed desorption of NO (NO-TPD) has been used for characterizing the support and catalysts from the point of view of $\mathrm{NO}$ activation on their surfaces. The NO-TPD experiments have been complemented by the in situ DRIFTS, which is extremely useful method for studying the binding states of adsorbed species. Fig. 3 and Table 3 show the NO-TPD curves and amounts of adsorbed and desorbed $\mathrm{NO}_{\mathrm{x}}$ species for the studied catalysts. As shown in Fig. 3a, two peaks of $\mathrm{NO}_{2}$ desorption occur for both the support and copper catalysts. The low temperature peaks may be ascribed to desorption of the weakly physisorbed $\mathrm{NO}_{2}$ species. The high temperature desorption peaks may be attributed to the strongly adsorbed $\mathrm{NO}_{2}$ species [26-28]. Analogously, two peaks of desorption are observed for the NO curve (Fig. 3b). It can be observed that the introduction of $\mathrm{CuO}$ to ceria-zirconia shifts the desorption peaks both for $\mathrm{NO}$ and $\mathrm{NO}_{2}$ into lower temperature. The addition of the metal phase $(\mathrm{CuO})$ shift a peaks of desorption to the lower temperature.

The amount of the adsorbed $\mathrm{NO}_{\mathrm{x}}$ species per $1 \mathrm{~g}$ of catalyst increase with the addition of active phase and is the highest for $\mathrm{Cu}(4) / \mathrm{CZ}$. The lowest amount adsorbed $\mathrm{NO}_{\mathrm{x}}$ species is for $\mathrm{Cu}(10) / \mathrm{CZ}$, which can be explained by the blocking of active sites in the $\mathrm{CuO}$ phase and, thus, the difficulty in the adsorption of $\mathrm{NO}_{\mathrm{x}}$ species. Another reason can be explained by the formation of agglomerates by $\mathrm{CuO}$, while for the catalyst with 2 and $4 \%$ amount of copper $\mathrm{CuO}$ can be well dispersed and the active sites are more available for $\mathrm{NO}_{\mathrm{x}}$ adsorption. It is interesting that the amount of adsorbed $\mathrm{NO}$ and desorbed $\mathrm{NO}_{\mathrm{x}}$ species on the studied catalysts is different. These phenomena can be explained by strong chemical adsorption of NO on the catalyst surface. Therefore, completely desorption of adsorbed NO species is difficult to observing in studied region of the temperature.

The results of in situ DRIFTS spectra $\mathrm{Cu}(10) / \mathrm{CZ}$ during $\mathrm{NO}$ by $\mathrm{O}_{2}$ at the catalyst surface at the temperatures ranging from RT to $400{ }^{\circ} \mathrm{C}$ are shown in Fig 4 . According to Hadjiivanov [29] and other authors [30-32], nitrogen oxides can be 

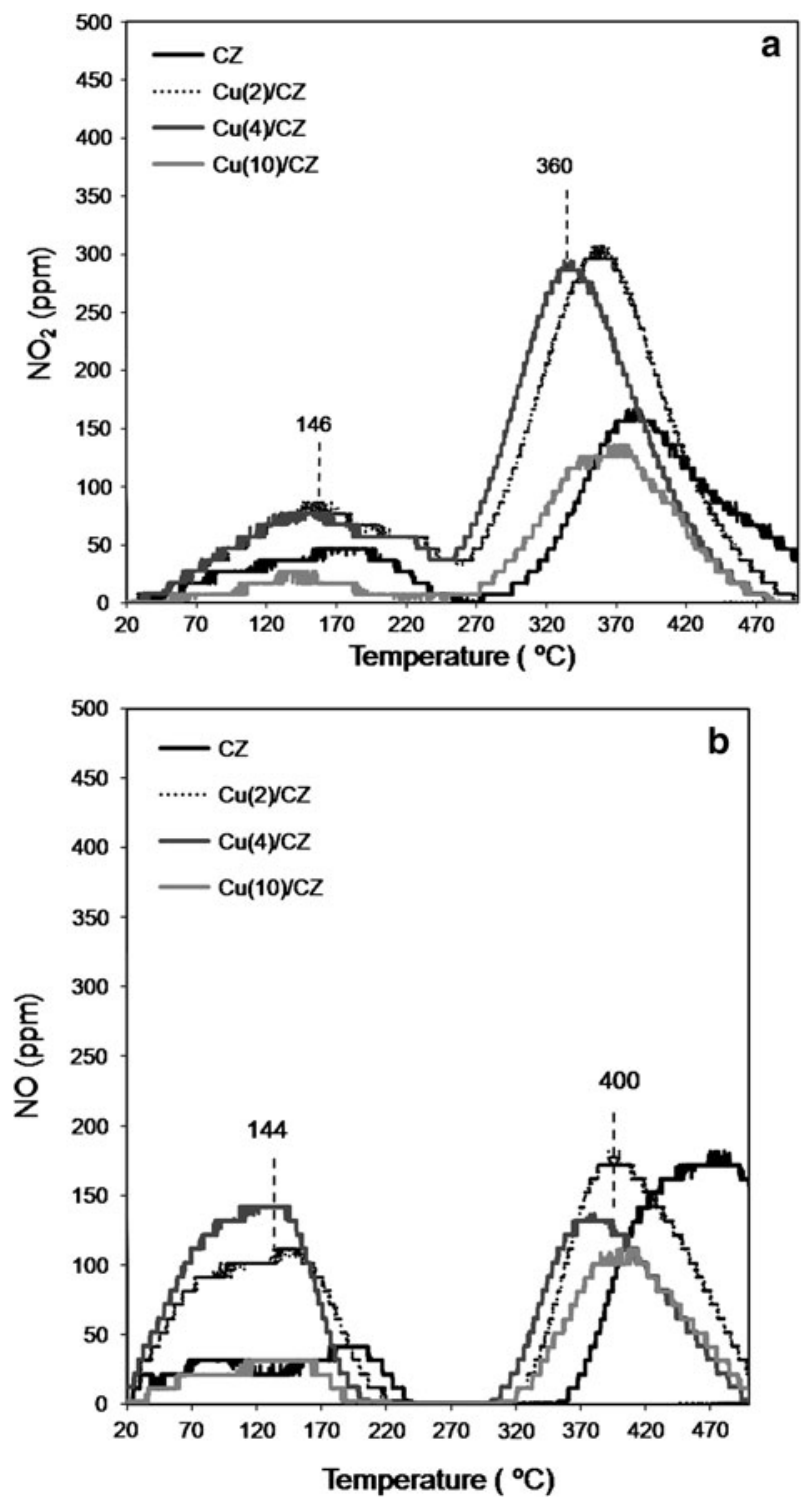

Fig. $3 \mathrm{NO}_{2}$ (a) and $\mathrm{NO}(\mathbf{b})$ evolution during NO-TPD carried out in the presence of $500 \mathrm{ppm}$ NO, $5 \%$ $\mathrm{O}_{2}$ on $C Z$ and $C u(2) / C Z, C u(4) / C Z, C u(10) / C Z$ catalysts

adsorbed on the catalyst surface forming nitrite $\left(\mathrm{NO}_{2}{ }^{-}\right)$or nitrate $\left(\mathrm{NO}_{3}{ }^{-}\right)$anions. When $\mathrm{NO}_{2}{ }^{-}$and $\mathrm{NO}_{3}{ }^{-}$ions are coordinated with cations by one or two of its oxygen atoms, the corresponding species are called nitrito and nitrato species, respectively. Nitrite $\left(\mathrm{NO}_{2}{ }^{-}\right)$and nitrate $\left(\mathrm{NO}_{3}{ }^{-}\right)$species can be monodentate, bidentate or bridging. Generally, the presence of bands at $1470-1375 \mathrm{~cm}^{-1}(\mathrm{v} \mathrm{N}=\mathrm{O})$ and $1206-1065 \mathrm{~cm}^{-1}$ (v $\mathrm{N}-\mathrm{O}$ ) corresponds to monodentate nitrito species. 
Table 3 The amount of adsorbed at RT and desorbed NO per $1 \mathrm{~g}$ of catalyst

\begin{tabular}{llll}
\hline Catalyst & $\begin{array}{l}\text { Amount of } \\
\text { adsorbed NO } \\
\text { species } \\
\left(\mu \mathrm{mol} \mathrm{g} \mathrm{g}_{\text {cat }}^{-1}\right)\end{array}$ & $\begin{array}{l}\text { Amount of desorbed } \\
\mathrm{NO}_{\mathrm{x}} \text { species } \\
\left(\mu \mathrm{mol} \mathrm{g} \mathrm{g}_{\text {cat }}^{-1}\right)\end{array}$ & $\begin{array}{l}\text { Percent of } \\
\text { desorbed } \mathrm{NO}_{\mathrm{x}} \\
\text { species }(\%)\end{array}$ \\
\hline $\mathrm{CZ}$ & 252 & 223 & 88.5 \\
$\mathrm{Cu}(2) / \mathrm{CZ}$ & 304 & 290 & 95.5 \\
$\mathrm{Cu}(4) / \mathrm{CZ}$ & 365 & 329 & 90.1 \\
$\mathrm{Cu}(10) / \mathrm{CZ}$ & 211 & 178 & 84.2 \\
\hline
\end{tabular}

Consequently, the bands at 1378 and $1453 \mathrm{~cm}^{-1}$, which are observed in Fig. 4, can be attributed to nitrite species. These bands are observed up to $200{ }^{\circ} \mathrm{C}$, and they decrease at higher temperatures. Simultaneously, absorptions at $1528,1609 \mathrm{~cm}^{-1}$ $\left(\mathrm{v}_{3}(\mathrm{~N}-\mathrm{O})\right)$, indicate formation of monodentate and bridging nitrato species. The bands at 1239 and $1196 \mathrm{~cm}^{-1}$ can be attributed to the nitrate or nitrite species. Hence, nitrites and nitrates are formed at low temperatures.

The surface oxygen interacts with NO from the gas phase to yield nitrite, which is related to electron transfer to the surface of catalyst [30]:

$$
\mathrm{NO}+\mathrm{O}^{2-} \rightarrow \mathrm{NO}_{2}^{-}+e^{-}
$$

The formation of some $\mathrm{NO}_{3}{ }^{-}$species at lower temperature may involve the surface reaction between the nitrite species with oxygen from the surface, Eq. 5, or as the result of the disproportionation of nitrite species, Eq. 6:

$$
\begin{gathered}
\mathrm{NO}_{2}^{-}+\mathrm{O}^{2-} \rightarrow \mathrm{NO}_{3}^{-}+2 e^{-} \\
3 \mathrm{NO}_{2}^{-} \rightarrow \mathrm{NO}_{3}^{-}+\mathrm{O}^{2-}+2 \mathrm{NO}
\end{gathered}
$$

The electrons in Eqs. 4 and 5 participate in the reduction of the active phase. When the temperature is increased, nitrites are transformed to nitrates. Consequently, nitrates can be decomposed to $\mathrm{NO}_{2}$, Eq. 7, or can react with $\mathrm{NO}$ from the gas phase, which results in nitrite and $\mathrm{NO}_{2}$ species, Eq. 8 .

$$
\begin{gathered}
2 \mathrm{NO}_{3}^{-} \rightarrow 2 \mathrm{NO}_{2}+\mathrm{O}^{2-} \\
\mathrm{NO}_{3}^{-}+\mathrm{NO} \rightarrow \mathrm{NO}_{2}^{-}+\mathrm{NO}_{2}
\end{gathered}
$$

At high temperature, the $\mathrm{NO}_{2}$ species are decomposed to $\mathrm{NO}$ according to thermodynamic equilibrium, Eq. 9.

$$
2 \mathrm{NO}_{2}=2 \mathrm{NO}+\mathrm{O}_{2}
$$

This can explain the presence of bands coming from $\mathrm{NO}_{2}{ }^{-}$and $\mathrm{NO}_{3}{ }^{-}$surface species (Figs. 4, 5) and the presence of $\mathrm{NO}$ and $\mathrm{NO}_{2}$ on NO-TPD profile (Fig. 3) $[30,32]$.

The above results were confirmed by DRIFTS studies of $\mathrm{Cu} / \mathrm{CZ}$ catalysts during NO-TPD. The NO-TPD experiments were preceded by the adsorption of $\mathrm{NO}+\mathrm{O}_{2} /$ Ar. The DRIFTS spectra during NO-TPD (Fig. 5) revealed the presence of bands at $1475 \mathrm{~cm}^{-1}$, which can be assigned to stretching vibrations of $\mathrm{N}-\mathrm{O}$ bond in 
Fig. 4 DRIFTS spectra of

$\mathrm{Cu}(10) / \mathrm{CZ}$ surface during adsorption of the $500 \mathrm{ppm} \mathrm{NO}$, $5 \% \mathrm{O}_{2}$

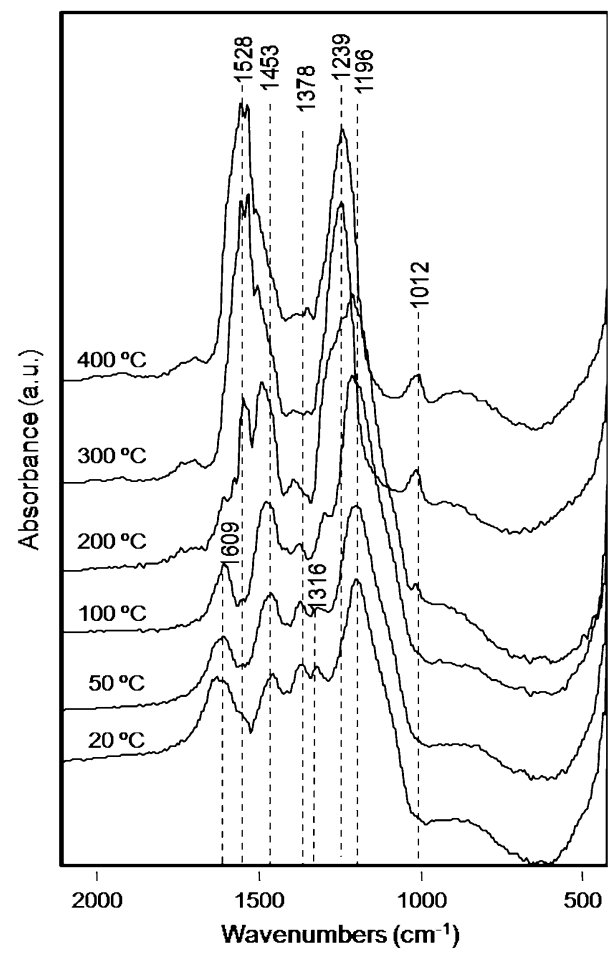

$\mathrm{NO}_{2}{ }^{-}$structure. The intensity of these bands increases with temperature up to $200{ }^{\circ} \mathrm{C}$ and then decreases. Simultaneously, three bands at 1534,1237 and $1033 \mathrm{~cm}^{-1}$ are shown. Their intensities are low below $200{ }^{\circ} \mathrm{C}$ but they increase significantly above this temperature. The DRIFTS spectra of $\mathrm{Cu}(10) / \mathrm{CZ}$ during NOTPD have shown that nitrites transform into nitrates when temperature increases. Moreover, the highest rate of the formation of surface nitrates is observed from 200 to $300{ }^{\circ} \mathrm{C}$. It is due to thermodynamic limitation, because simultaneously nitrates decompose into nitrites above $300{ }^{\circ} \mathrm{C}$. Hence, further increase of absorptions up to $400{ }^{\circ} \mathrm{C}$ for bands at $1534,1237 \mathrm{~cm}^{-1}$ is practically not observed.

\section{DRITS of $\mathrm{NH}_{3}$ adsorption}

Because ammonia is considered as an active reductant in process of $\mathrm{NO}_{\mathrm{x}}$ reduction, it is important to know in which way ammonia interacts with the catalyst surface. It is well known that one of the methods for determined adsorption ammonia and surface acidity is DRIFT [31].

The DRIFT spectra of adsorbed species on the $\mathrm{Cu} / \mathrm{CZ}$ surface resulting from ammonia adsorption at different temperatures are shown in Fig. 6. According to many authors, adsorption of ammonia can proceed at the Brønsted or Lewis acid sites, forming $\mathrm{NH}_{4}{ }^{+}$or adsorbed $\mathrm{NH}_{3}[33,34]$. When ammonia is adsorbed on the Brønsted acid sites, the bands in the $1480-1395 \mathrm{~cm}^{-1}$ region of absorption can be 
Fig. 5 DRIFT spectra of $\mathrm{Cu}(10) / \mathrm{CZ}$ surface after adsorption of the $500 \mathrm{ppm}$ NO, $5 \% \mathrm{O}_{2}$

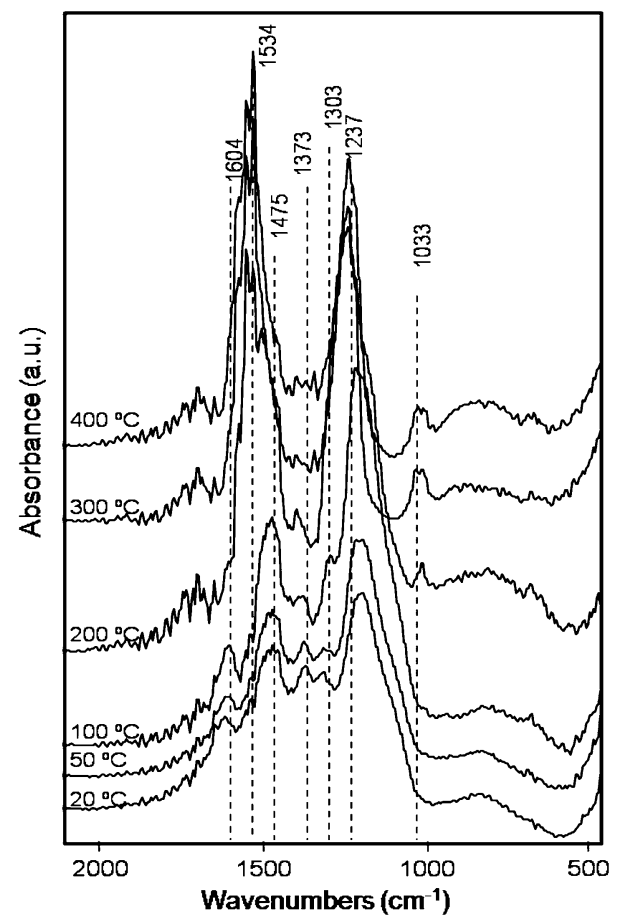

observed [2, 10, 34]. Thus, the bands at 1459 and $1395 \mathrm{~cm}^{-1}$ for $\mathrm{Cu}(10) / \mathrm{CZ}$ are attributed to these ammonia species. The absorption bands assigned to the ammonia adsorbed on the Lewis acid sites are observed at 1211 and $1647 \mathrm{~cm}^{-1}[2,10,33]$. For the $\mathrm{Cu}(10) / \mathrm{CZ}$ catalyst, the bands at $1647 \mathrm{~cm}^{-1}$ disappear at $200{ }^{\circ} \mathrm{C}$, whereas absorptions band at $1211 \mathrm{~cm}^{-1}$ increase up to $400{ }^{\circ} \mathrm{C}$. During the temperature programmed surface reaction of the $\mathrm{Cu}(10) / \mathrm{CZ}$ catalyst with ammonia, the bands corresponding to $\mathrm{NH}_{3}$ adsorbed on the Lewis and Brønsted acid strength decrease. Therefore, new bands at $1528 \mathrm{~cm}^{-1}$ are observed and they can be attributed to the $\mathrm{NH}_{2}$ species. We proposed the formation of $\mathrm{NH}_{2}$ species on the catalysts surface as the results of $\mathrm{H}$ or $2 \mathrm{H}$ abstraction from coordinated $\mathrm{NH}_{3}$ or $\mathrm{NH}_{4}{ }^{+}$on the catalyst surface, respectively, Eqs. 10 and 11 [2, 10, 33].

$$
\begin{aligned}
& \mathrm{NH}_{3(\text { ads })} \rightarrow \mathrm{NH}_{2(\text { ads })}+\mathrm{H}^{+}+e^{-} \\
& \mathrm{NH}_{4(\text { ads })}^{+} \rightarrow \mathrm{NH}_{2(\text { ads })}+2 \mathrm{H}^{+}+e^{-}
\end{aligned}
$$

The electrons forming in the above reactions are transfer to the surface of catalyst. The absorption assigned to the coordinated $\mathrm{NH}_{3}$ species are observed at $1300 \mathrm{~cm}^{-1}$ and other bands, appearing at $1070-1020 \mathrm{~cm}^{-1}$ region and can be assigned to the adsorption of ammonia on the surface oxygen atoms via hydrogen bonding [33].

The surface acidity was confirmed by the adsorption of ammonia both on the Lewis and Brønsted acid sites. Moreover, during temperature programmed surface 
Fig. 6 DRIFT spectra of $\mathrm{Cu}(\mathrm{y} 10) / \mathrm{CZ}$ surface during adsorption of the $500 \mathrm{ppm} \mathrm{NH}_{3}$

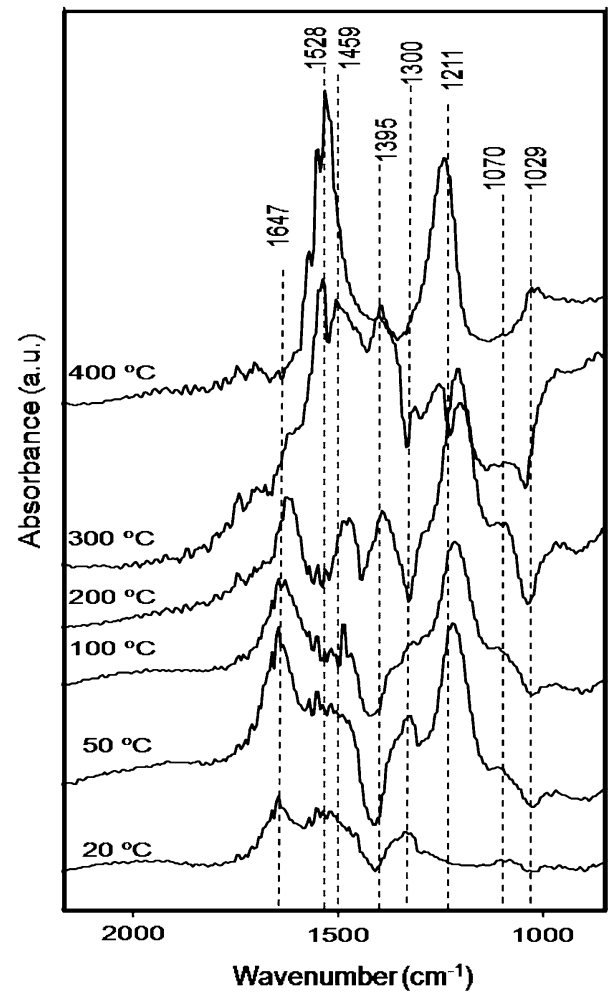

reaction these acid sites have been disappeared and the band new absorptions of $\mathrm{NH}_{2}$ species are formed.

\section{Conclusions}

The $\mathrm{CuO} / \mathrm{CZ}$ catalysts with different amounts of copper oxide were synthesized. The structural, redox, acidic and adsorption properties were investigated. Surface acidity was studied by DRIFT spectra of the adsorbed $\mathrm{NH}_{3}$ species. The ammonia was adsorbed on the Lewis and Brønsted acid sites and it was transformed into the $\mathrm{NH}_{2}$ species when temperature was increased. From the NO-TPD results, it was calculated that the amount of adsorbed NO species increased after addition of the copper. It was the highest for $\mathrm{Cu}(4) / \mathrm{CZ}$. The $\mathrm{CuO}$ could be well dispersed in the case of $\mathrm{Cu}(4) / \mathrm{CZ}$ catalyst. For this metal loading, the active sites are more available for $\mathrm{NO}$ adsorption than for $\mathrm{Cu}(10) / \mathrm{CZ}$ catalyst, in which $\mathrm{CuO}$ can form agglomerates, and consequently it is difficult to adsorb NO species. The presented work has shown that the ceria-zirconia supported copper catalysts are able to oxidize $\mathrm{NO}$ to $\mathrm{NO}_{2}$ even at low temperature. It can be explained by the strong oxidizing properties of the surface oxygen of ceria-zirconia. From the DRIFT spectra, it was observed that NO can adsorbed on the catalysts surface to form 
nitrate and nitrite species. Nitrites are formed by electron transfer from NO to the catalyst and they are transformed to nitrate species via oxygen transfer promoted letter in presence of $\mathrm{NO}_{2}$. The nitrite species are subsequently transformed into nitrates when temperature increases up to $300{ }^{\circ} \mathrm{C}$. The rate of surface nitrate formation also increases with temperature. Above $300{ }^{\circ} \mathrm{C}$, the absorption bands of the nitrates disappear because of their decomposition to nitrites which are due to thermodynamic limitations. The results of DRIFT spectroscopy were consistent with the results of NO-TPD experiments. By the observation of the functional groups evolution, several surface reactions have been proposed.

Open Access This article is distributed under the terms of the Creative Commons Attribution License which permits any use, distribution, and reproduction in any medium, provided the original author(s) and the source are credited.

\section{References}

1. Zhu J, Thomas A (2009) Perovskite-type mixed oxides as catalytic material for NO removal. Appl Catal B 92:225-233

2. Si Z, Weng D, Wu X, Li J, Li G (2010) Structure, acidity and activity of $\mathrm{CuO}_{\mathrm{x}} / \mathrm{WO}_{\mathrm{x}}-\mathrm{ZrO}_{2}$ catalyst for selective catalytic reduction of $\mathrm{NO}$ by $\mathrm{NH}_{3}$. J Catal 271:43-51

3. Casapu M, Bernhard A, Peitz D, Mehring M, Elsener M, Kröcher O (2011) A Niobia-Ceria based multi-purpose catalyst for selective catalytic reduction of $\mathrm{NO}_{\mathrm{x}}$ urea hydrolysis and soot oxidation in diesel exhaust. Appl Catal B 103:79-84

4. Iwamoto S, Takahashi R, Inoue M (2007) Direct decomposition of nitric oxide over Ba catalyst supported on $\mathrm{CeO}_{2}$-based mixed oxides. Appl Catal B 70:146-160

5. Gómez-García MA, Pitchon V, Kiennemann A (2005) Pollution by nitrogen oxides: an approach to $\mathrm{NO}_{x}$ abatement by using sorbing catalytic materials. Environ Intern 31:445-467

6. Boyanoa A, Lázaroa MJ, Cristiani C, Maldonado-Hodarc FJ, Forzatti P, Molinera R (2009) A comparative study of $\mathrm{V}_{2} \mathrm{O}_{5} / \mathrm{AC}$ and $\mathrm{V}_{2} \mathrm{O}_{5} / \mathrm{Al}_{2} \mathrm{O}_{3}$ catalysts for the selective catalytic reduction of $\mathrm{NO}$ by $\mathrm{NH}_{3}$. Chem Eng J 149:173-182

7. Liu F, He H, Ding Y, Zhang Ch (2009) Effect of manganese substitution on the structure and activity of iron titanate catalyst for the selective catalytic reduction of $\mathrm{NO}$ with $\mathrm{NH}_{3}$. Appl Catal B 93:194-204

8. Xu W, Yu Y, Zhang Ch, He H (2008) Selective catalytic reduction of NO by $\mathrm{NH}_{3}$ over a Ce/TiO catalyst. Catal Comm 9:1453-1457

9. Irfan MF, Goo JH, Kim SD (2008) $\mathrm{Co}_{3} \mathrm{O}_{4}$ based catalysts for $\mathrm{NO}$ oxidation and $\mathrm{NO}_{\mathrm{x}}$ reduction in fast SCR process. Appl Catal B 78:267-274

10. Liu F, He H, Zhang Ch, Shen W (2011) Mechanism of the selective catalytic reduction of $\mathrm{NO}_{\mathrm{x}}$ with $\mathrm{NH}_{3}$ over environmental-friendly iron titanate catalyst. Catal Today 175:18-25

11. Pietrogiacomi D, Magliano A, Sannino D, Campa MC, Ciambelli P, Indovina V (2005) In situ sulphated $\mathrm{CuO}_{\mathrm{x}} / \mathrm{ZrO}_{2}$ and $\mathrm{CuO}_{\mathrm{x}} /$ sulphated- $\mathrm{ZrO}_{2}$ as catalysts for the reduction of $\mathrm{NO}_{\mathrm{x}}$ with $\mathrm{NH}_{3}$ in the presence of excess $\mathrm{O}_{2}$. Appl Catal B 60:83-92

12. Damyanova S, Pawelec B, Arishtirova K, Martinez Huerta MV, Fierro JLG (2008) Study of the surface and redox properties of ceria-zirconia oxides. Appl Catal A 337:86-96

13. Liu L, Yu Q, Zhu J, Wana H, Sun K, Liu B, Zhu H, Gao F, Dong L, Chen Y (2010) Effect of MnO modification on the activity and adsorption of $\mathrm{CuO} / \mathrm{Ce}_{0,67} \mathrm{Zr}_{0,33}$ catalyst for $\mathrm{NO}$ reduction. $\mathrm{J}$ Colloid Interface Sci 349:246-255

14. Adamowska M, Krzton A, Najbar M, Camra J, Djega-Mariadassou G, Da Costa P (2009) Ceriazirconia-supported rhodium catalyst for $\mathrm{NO}_{x}$ reduction from coal combustion flue gases. Appl Catal B 90:353-544

15. Adamowska M, Muller S, Da Costa P, Krzton A, Burg P (2007) Correlation between the surface properties and deNO $\mathrm{N}_{\mathrm{x}}$ activity of ceria-zirconia catalysts. Appl Catal B 74:278-289

16. Adamski A, Tabor E, Gil B, Sojka Z (2007) Interaction of $\mathrm{NO}$ and $\mathrm{NO}_{2}$ with the surface of $\mathrm{Ce}_{x} \mathrm{Zr}_{1-x} \mathrm{O}_{2}$ solid solutions-influence of the phase composition. Catal Today 119:114-119 
17. JCPDS 01-078-0694

18. Atribak I, Guillén-Hurtado N, Bueno-López A, García-García A (2010) Influence of the physicochemical properties of $\mathrm{CeO}_{2}-\mathrm{ZrO}_{2}$ mixed oxides on the catalytic oxidation of $\mathrm{NO}$ to $\mathrm{NO}_{2}$. Appl Surf Sci 256:7706-7712

19. JCPDS 04-009-2287

20. Ayastuy JL, Gurbani A, Gonzales-Marcus MP, Gutierrez-Ortiz MA (2012) Selective CO oxidation in $\mathrm{H}_{2}$ streams on $\mathrm{CuO} / \mathrm{Ce}_{\mathrm{x}} \mathrm{Zr}_{1-\mathrm{x}} \mathrm{O}_{2}$ catalysts: correlation between activity and low temperature reducibility. Int J Hydrogen Energy 37:1993-2006

21. Trovarelli A, De Leitenburg C, Dolcetti G, Lorca JL (1995) $\mathrm{CO}_{2}$ methanation under transient and steady-state conditions over $\mathrm{Rh} / \mathrm{CeO}_{2}$ and $\mathrm{CeO}_{2}$-promoted $\mathrm{Rh} / \mathrm{SiO}_{2}$ : the role of surface and bulk ceria. J Catal 151:111-124

22. Gutierez-Ortiz JI, De Rivas B, López-Fonsea R, Gonzàles-Velasco JR (2005) Characterization of the catalytic properties of ceria-zirconia mixed oxides by temperature programmed techniques. J Thermal 80:225-228

23. Li G, Wang Q, Zhao B, Zhao R (2010) Modification for $\mathrm{Ce}_{0,67} \mathrm{Zr}_{0,33} \mathrm{O}_{2}$ mixed oxides by coprecipitated/impregnated Co: effect on the surface and catalytic behaviour of Pd only three-way catalyst. J Mol Catal A 326:69-74

24. Zhou R, Yu T, Jiang X, Chen F, Zheng X (1999) Temperature programmed reduction and temperature-programmed desorption studies of $\mathrm{CuO} / \mathrm{ZrO}_{2}$ catalysts. Appl Surf Sci 148:263-270

25. Teng M, Lou L, Yang X (2009) Synthesis of mesoporous $\mathrm{Ce}_{1-\mathrm{x}} \mathrm{Zr}_{\mathrm{x}} \mathrm{O}_{2}(\mathrm{x}=0.2-0.5)$ and catalytic properties of $\mathrm{CuO}$ based catalysts. Microporous Mesoporous Mater 119:158-164

26. Wu X, Lin F, Xu H, Weng D (2010) Effects of adsorbed and gaseous $\mathrm{NO}_{\mathrm{x}}$ species on catalytic oxidation of diesel soot with $\mathrm{MnO}_{\mathrm{x}}-\mathrm{CeO}_{2}$ mixed oxides. Appl Catal B 95:101-109

27. Wang Y, Zhu A, Zhang Y, Au CT, Yang X, Shi C (2008) Catalytic reduction of NO by CO over NiO/ $\mathrm{CeO}_{2}$ catalyst in stoichiometric $\mathrm{NO} / \mathrm{CO}$ and $\mathrm{NO} / \mathrm{CO} / \mathrm{O}_{2}$ reaction. Appl Catal B 81:141-149

28. Li WB, Yang XF, Chen LF, Wang JA (2009) Adsorption/desorption of $\mathrm{NO}_{\mathrm{x}}$ on $\mathrm{MnO}_{2} / \mathrm{ZrO}_{2}$ oxides prepared in reverse microemulsions. Catal Today 148:75-80

29. Hadjiivanov KI (2000) Catal Rev Sci Eng 42:71

30. Adamowska M, Krzton A, Najbar M, Da Costa P, Djega-Mariadassou G (2008) DRIFT study of the interaction of $\mathrm{NO}$ and $\mathrm{O}_{2}$ with the surface of $\mathrm{Ce}_{0.62} \mathrm{Zr}_{0.38} \mathrm{O}_{2}$ as deNO $\mathrm{O}_{x}$ catalyst. Catal Today 137:288-291

31. Little LH (1966) Infrared spectra of adsorbed species. Academic Press, London

32. Azambre B, Zenboury L, Delacroix F, Weber JV (2008) Adsorption of $\mathrm{NO}$ and $\mathrm{NO}_{2}$ on ceriazirconia of composition $\mathrm{Ce}_{0.69} \mathrm{Zr}_{0.31} \mathrm{O}_{2}$ : a DRIFTS study. Catal Today 137:278-282

33. Davydov A (2003) Molecular spectroscopy of oxide catalyst surface. Wiley, England

34. Casapu M, Krocher O, Mehring M, Nachtegaal M, Borca C, Harfouche M, Grolimund D (2010) Characterization of $\mathrm{Nb}$-containing $\mathrm{MnO}_{\mathrm{x}}-\mathrm{CeO}_{2}$ catalyst for low temperature selective catalytic reduction of $\mathrm{NO}$ with $\mathrm{NH}_{3}$. J Phys Chem C 114:9791-9801 